\title{
Development of an RIA for salmon 41 kDa IGF-binding protein
}

\author{
M Shimizu ${ }^{1}$, A Hara ${ }^{2}$ and W W Dickhoff ${ }^{1}$ \\ Northwest Fisheries Science Center, National Marine Fisheries Service, 2725 Montlake Boulevard East, Seattle, Washington 98112, USA \\ ${ }^{1}$ School of Aquatic and Fishery Sciences, University of Washington, Seattle, Washington 98195, USA \\ ${ }^{2}$ Graduate School of Fisheries Sciences, Hokkaido University, 3-1-1, Minato, Hakodate, Hokkaido 041-8611, Japan \\ (Requests for offprints should be addressed to M Shimizu who is now at Northwest Fisheries Science Center, National Marine Fisheries Service, \\ 2725 Montlake Boulevard East, Seattle, Washington 98112, USA; Email: munetaka.shimizu@noaa.gov)
}

\begin{abstract}
Salmon plasma contains at least three IGF-binding proteins (IGFBPs) with molecular masses of 41, 28 and $22 \mathrm{kDa}$. The $41 \mathrm{kDa}$ IGFBP is similar to mammalian IGFBP-3 in size, type of glycosylation and physiological responses. In this study, we developed an RIA for the $41 \mathrm{kDa}$ IGFBP. The $41 \mathrm{kDa}$ IGFBP purified from serum was used for antibody production and as an assay standard. Binding of three different preparations of tracer were examined: ${ }^{125}$ I-41 kDa IGFBP, ${ }^{125}$ I-41 kDa IGFBP cross-linked with IGF-I and $41 \mathrm{kDa}$ IGFBP cross-linked with ${ }^{125} \mathrm{I}-$ IGF-I (41 kDa IGFBP/ $\left./{ }^{125} \mathrm{I}-\mathrm{IGF}-\mathrm{I}\right)$. Only binding of $41 \mathrm{kDa}$ IGFBP $/ 125$ I-IGF-I was not affected by added IGFs, and therefore it was chosen for the tracer in the RIA. Plasma $41 \mathrm{kDa}$ IGFBP levels measured by RIA were increased by GH treatment $(178.9 \pm 4.9 \mathrm{ng} / \mathrm{ml})$ and
\end{abstract}

decreased after fasting $(95 \cdot 0 \pm 7 \cdot 0 \mathrm{ng} / \mathrm{ml})$. The molarities of plasma $41 \mathrm{kDa}$ IGFBP and total IGF-I were comparable, and they were positively correlated, suggesting that salmon $41 \mathrm{kDa}$ IGFBP is a main carrier of circulating IGF-I in salmon, as is mammalian IGFBP-3 in mammals. During the parr-smolt transformation (smoltification) of coho salmon, plasma $41 \mathrm{kDa}$ IGFBP levels showed a transient peak $(182.5 \pm 10.3 \mathrm{ng} / \mathrm{ml})$ in March and stayed relatively constant thereafter, whereas IGF-I showed peak levels in March and April. Differences in the molar ratio between $41 \mathrm{kDa}$ IGFBP and IGF-I possibly influence availability of IGF-I in the circulation during smoltification.

Journal of Endocrinology (2003) 178, 275-283

\section{Introduction}

Insulin-like growth factor (IGF)-binding proteins (IGFBPs) are important modulators of IGF actions, controlling IGF availability to IGF receptors in the target tissues. In mammals, six IGFBPs have been identified, and their regulation and functions have been extensively studied (for reviews see Shimasaki \& Ling 1991, Rechler 1993, Jones \& Clemmons 1995, Rajaram et al. 1997). Recent findings also indicate IGF-independent actions of IGFBPs on cell growth in many mammalian cell types (for review see Mohan \& Baylink 2002). IGF and IGFBP are evolutionary ancient proteins, since both molecules are found in lamprey (Geotria australis; Upton et al. 1993). In fish, IGFBPs corresponding to mammalian IGFBP-1 and -2 have been cloned in zebrafish (Danio rerio; Duan et al. 1999, Maures \& Duan 2002) and gilthead sea bream (Sparus aurata, Funkenstein et al. 2002), and an almost complete sequence has been reported for tilapia (Oreochromis mossambicus) IGFBP-3 (Cheng et al. 2002). Multiple IGFBPs have been detected in fish plasma/serum by Western ligand blotting using labeled IGF-I and have been shown to be controlled by hormones, nutritional status and stress (Kelley et al. 1992, 2001, Niu \& Le Bail 1993, Siharath et al. 1995, 1996, Shimizu et al. 1999, Park et al. 2000). Duan and co-workers showed that fish IGFBPs expressed in animal cells or purified from culture medium inhibit IGF-stimulated DNA synthesis in vitro (Duan et al. 1999, Bauchat et al. 2001). These findings indicate that fish IGFBPs are conserved functionally as well as structurally.

To date, most studies on physiological regulation of fish IGFBPs have been conducted by use of Western ligand blotting. Although Western ligand blotting is a powerful tool to detect different types of IGFBPs and to compare their relative concentrations, this technique is semiquantitative and not suitable for processing a large number of samples. Development of an RIA for fish IGFBPs would greatly facilitate study of the physiological regulation of fish IGFBPs by providing a precise, high capacity tool. In salmon, at least three IGFBPs with molecular masses of 41, 28 and $22 \mathrm{kDa}$ exist in plasma. The $41 \mathrm{kDa}$ IGFBP is most likely the salmon IGFBP-3, since it has a molecular mass similar to mammalian IGFBP-3 and its plasma levels are influenced by growth hormone $(\mathrm{GH})$ treatment and fasting, as is mammalian IGFBP-3 (Shimizu et al. 1999). 
We recently purified the salmon $41 \mathrm{kDa}$ IGFBP from serum (Shimizu et al. 2003) and generated a specific antibody against it. Using this antibody and purified protein as assay components, we developed an RIA for salmon $41 \mathrm{kDa}$ IGFBP.

\section{Materials and Methods}

Fish

Spawning male chinook salmon (Oncorhynchus tshawytscha) were sampled for blood in the adult return pond on the University of Washington campus, Seattle, WA, USA in October and November 1999-2001. Fish were anesthetized in $0.05 \%$ tricane methanesulfonate (MS-222; Argent Chemical Laboratories, Redmond, WA, USA). Blood was withdrawn by syringe from the caudal veins, allowed to clot overnight at $4{ }^{\circ} \mathrm{C}$ and then centrifuged at $1350 \mathrm{~g}$ for $30 \mathrm{~min}$. Serum was collected and stored at $-80^{\circ} \mathrm{C}$ until use.

Two-year-old coho salmon (Oncorhynchus kisutch) were reared in fresh water at the Northwest Fisheries Science Center in Seattle, WA, USA. They were maintained in recirculated fresh water in circular fiberglass tanks under natural photoperiod; flow rate was $25 \mathrm{l} / \mathrm{min}$; temperature ranged from 10.5 to $13.0{ }^{\circ} \mathrm{C}$. Fish were fed standard rations $(0 \cdot 6-1 \cdot 0 \%$ body weight/day) of a commercial diet (Biodiet Grower; Bioproducts Inc., Warrenton, OR, USA). Some of the 2-year-old coho salmon were injected twice with salmon $\mathrm{GH}$ at a dose of $0 \cdot 1 \mu \mathrm{g} / \mathrm{g}$ body weight or saline, and sampled $24 \mathrm{~h}$ after the second injection (48 h after first injection) as described in Shimizu et al. (1999). Other groups were fasted or fed freely for 1 month (Shimizu et al. 1999). Blood was withdrawn by cutting the caudal peduncle and letting blood flow into a heparinized glass tube. Plasma was collected after centrifugation at $700 \boldsymbol{g}$ for $15 \mathrm{~min}$ and stored at $-80{ }^{\circ} \mathrm{C}$ until use.

One-year-old coho salmon were reared under the same conditions as described above. From 2 March to 6 July 2000, 12 fish were sampled for blood every 2 weeks. Fork length and body weight of the fish at the beginning of the sampling were $12.3 \pm 0.2 \mathrm{~cm}$ (mean \pm S.E.M.) and $21.7 \pm$ $0.9 \mathrm{~g}$ respectively, and those at the end of the sampling were $15 \cdot 8 \pm 0.3 \mathrm{~cm}$ and $47.2 \pm 2.8 \mathrm{~g}$ respectively. Condition factor was calculated as: (body weight) $\times 1000 /$ (fork length $)^{3}$. All experiments were carried out in accordance with the guidelines of the University of Washington Institutional Animal Care and Use Committee.

\section{Purification of IGFBP}

The $41 \mathrm{kDa}$ IGFBP was purified from serum of spawning male chinook salmon as described in Shimizu et al. (2003). Briefly, salmon serum was acidified with $2 \mathrm{M}$ acetic acid, $0.75 \mathrm{mM} \mathrm{NaCl}$ and mixed with SP-Sephadex C-25
(Pharmacia, Uppsala, Sweden). The gel was settled out after incubating for $1 \mathrm{~h}$ and the supernatant was collected. The supernatant was neutralized with $7 \mathrm{M} \mathrm{NaOH}$ and a heavy precipitate was removed by centrifugation. Clarified supernatant was loaded onto an IGF-I affinity column and IGFBPs were eluted from the column with $0.5 \mathrm{M}$ acetic acid. IGFBPs were further purified by reversed-phase HPLC using a Vydac C-4 column (Separation Group, Hesperia, CA, USA).

\section{Preparation of antiserum}

Polyclonal antiserum against purified $41 \mathrm{kDa}$ IGFBP (anti$41 \mathrm{kDa}$ IGFBP) was raised in a rabbit. Immunization of the rabbit was conducted in accordance with the guidelines of the animal care committee of Hokkaido University. A total of $145 \mu \mathrm{g}$ purified protein in $1 \mathrm{ml}$ were emulsified in an equal volume of Freund's complete adjuvant (Iatoron, Tokyo, Japan). The rabbit was first immunized with $25 \mu \mathrm{g}$ antigen by lymph node injection and boosted twice with $60 \mu \mathrm{g}$ antigen at multiple subcutaneous sites on the back, 3 and 5 weeks after the first injection. Blood was withdrawn from the ear vein and antiserum was collected after centrifugation. The antiserum was stored at $-30{ }^{\circ} \mathrm{C}$ until use.

\section{Western ligand blotting and Western blotting}

SDS-PAGE with a $3 \%$ stacking gel and $12 \cdot 5 \%$ separating gel was carried out according to Laemmli (1970). Purified salmon IGFBPs were treated with an equal volume of the sample buffer containing $2 \%$ SDS, $10 \%$ glycerol at $85{ }^{\circ} \mathrm{C}$ for $5 \mathrm{~min}$. Gels were run in a solution of $50 \mathrm{mM}$ Tris, $400 \mathrm{mM}$ glycine and $0 \cdot 1 \%$ SDS at $50 \mathrm{~V}$ in the stacking gel and at $100 \mathrm{~V}$ in the separating gel until the bromophenol blue dye front reached the bottom of the gel.

Western ligand blotting using digoxigenin-labeled human IGF-I (DIG-hIGF-I) was carried out as described in Shimizu et al. (2000). After electroblotting, the nitrocellulose membrane was incubated with $9 \mathrm{ng} / \mathrm{ml} \mathrm{DIG-}$ hIGF-I for $2 \mathrm{~h}$ at room temperature and then incubated with antibody against DIG conjugated to horseradish peroxidase (HRP) (Boehringer Mannheim, Indianapolis, IN, USA) at a dilution of $1: 2500$ for $1 \mathrm{~h}$ at room temperature. IGFBPs were visualized on X-ray film by use of ECL Western blotting reagents (Amersham Life Science Inc., Arlington Heights, IL, USA).

For immunoblotting, an electroblotted nitrocellulose membrane was incubated with anti-41 kDa IGFBP serum at a dilution of 1:1500 for $2 \mathrm{~h}$ at room temperature. The membrane was then incubated with goat anti-rabbit IgG-HRP conjugate (Bio-Rad, Hercules, CA, USA) for $1 \mathrm{~h}$ at room temperature. Immunoreactive bands were visualized on X-ray film by use of ECL Western blotting reagents. 


\section{Preparation of tracers}

Purified $41 \mathrm{kDa}$ IGFBP was iodinated with $0.5 \mathrm{mCi}$ $\mathrm{Na}^{125} \mathrm{I}$ (Amersham Life Science Inc.) by the chloramine-T method as described in Moriyama et al. (1994). Five micrograms of the $41 \mathrm{kDa}$ IGFBP in $36 \mu \mathrm{l}$ were mixed with $64 \mu \mathrm{l} 0.5 \mathrm{M}$ phosphate buffer, $\mathrm{pH} 7 \cdot 4$. The mixture was reacted with $20 \mu \mathrm{l} 0 \cdot 4 \mathrm{mg} / \mathrm{ml}$ chloramine-T (Sigma, St Louis, MO, USA ) for $90 \mathrm{~s}$ and $20 \mu \mathrm{l} 0.6 \mathrm{mg} / \mathrm{ml}$ metabisulfite were added to stop the reaction. Iodinated $41 \mathrm{kDa}$ IGFBP (IGFBP*) was separated from free $\mathrm{Na}^{125} \mathrm{I}$ using Biogel P-6 $(1 \times 18 \mathrm{~cm}$; Bio-Rad $)$. Specific activity of the tracer estimated by the self-displacement assay (Catt 1976) was $29 \cdot 8 \mu \mathrm{Ci} / \mu \mathrm{g}$.

An aliquot of IGFBP* $(1.8 \mu \mathrm{g})$ was incubated with $3 \cdot 3 \mu \mathrm{g}$ salmon IGF-I (GroPep Pty Ltd, Adelaide, Australia) for $2 \mathrm{~h}$ and they were cross-linked by disuccinimidyl suberate (Pierce, Rockford, IL, USA) according to manufacturer's instruction. The IGFBP* cross-linked with salmon IGF-I (IGFBP*/IGF-I) was separated from nonreacted IGF-I by gel filtration using $1 \times 18 \mathrm{~cm}$ column of Sephadex G-50 Superfine (Pharmacia). Specific activity of the tracer was $49 \cdot 2 \mu \mathrm{Ci} / \mu \mathrm{g}$.

A tracer consisting of unlabeled $41 \mathrm{kDa}$ IGFBP and ${ }^{125}$ I-salmon IGF-I was also prepared. Salmon IGF-I was iodinated by the chloramine-T method as described above and an aliquot of ${ }^{125}$ I-salmon IGF-I $(1 \mu \mathrm{g})$ was incubated with $6.7 \mu \mathrm{g}$ purified $41 \mathrm{kDa}$ IGFBP for $2 \mathrm{~h}$, and they were cross-linked by disuccinimidyl suberate. The $41 \mathrm{kDa}$ IGFBP cross-linked with ${ }^{125}$ I-salmon IGF-I (IGFBP/ IGF-I*) was separated from non-reacted ${ }^{125} \mathrm{I}$-salmon IGF-I by gel filtration using Sephadex G-50. Specific activity of the tracer was $6 \cdot 6 \mu \mathrm{Ci} / \mu \mathrm{g}$.

\section{RIA for $41 k D a I G F B P$}

RIA was carried out in $12 \times 75 \mathrm{~mm}$ polystyrene test tubes. Purified $41 \mathrm{kDa}$ IGFBP was used for the standard. One hundred microliters of standard or plasma diluted in $20 \mathrm{mM}$ phosphate, $150 \mathrm{mM} \mathrm{NaCl}$ containing 1.0\% BSA and $0 \cdot 05 \%$ Triton X-100 were incubated with $100 \mu \mathrm{l}$ anti-41 kDa IGFBP at a dilution of 1:3000-5000 overnight at $4{ }^{\circ} \mathrm{C}$. Approximately 7000 c.p.m. tracer in $100 \mu \mathrm{l}$ were added to the tubes and incubated overnight at $4{ }^{\circ} \mathrm{C}$. Free and antibody-bound tracers were separated by the addition of $0.5 \%$ Pansorbin (Calbiochem-Novabiochem Corp., La Jolla, CA, USA). After incubating overnight at $4{ }^{\circ} \mathrm{C}$, tubes were centrifuged at $1350 \mathrm{~g}$ for $30 \mathrm{~min}$ and the supernatant was aspirated. Radioactivity in the pellets was measured by a gamma counter (Packard, Meriden, CT, USA).

\section{RIA for IGF-I}

IGF-I was extracted from plasma by acid-ethanol followed by cryoprecipitation according to the method of Breier

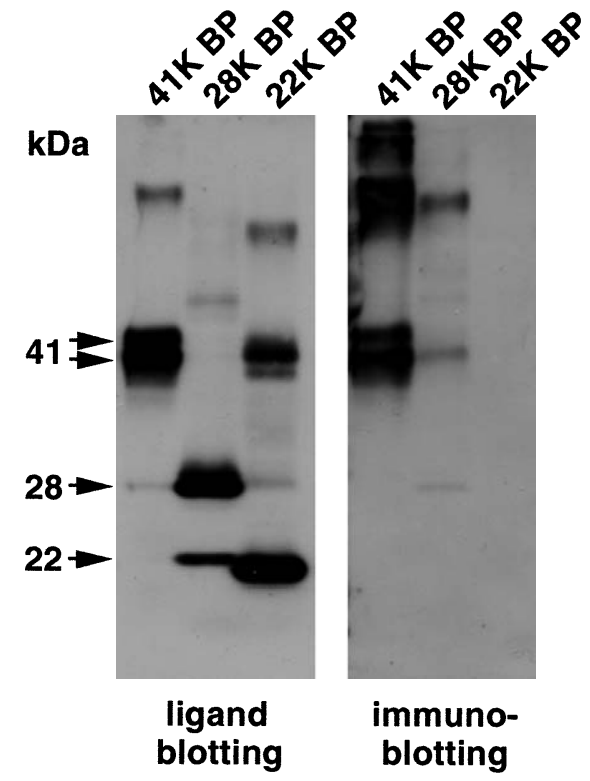

Figure 1 Ligand blotting using DIG-hIGF-I (left) and immunoblotting using anti-41 kDa IGFBP (right) of purified salmon IGFBPs. Fifty nanograms of each IGFBP fraction were separated by $12 \cdot 5 \%$ SDS-PAGE under non-reducing conditions and transferred to a nitrocellulose membrane. For ligand blotting, the nitrocellulose membrane was incubated with $9 \mathrm{ng} / \mathrm{ml}$ DIG-hIGF-I for $2 \mathrm{~h}$ and then with anti-DIG conjugated to HRP at a dilution of 1:2500 for $1 \mathrm{~h}$. For immunoblotting, the nitrocellulose membrane was incubated with anti-41 kDa IGFBP at a dilution of 1:1500 for $2 \mathrm{~h}$ and then with anti-rabbit IgG conjugated to HRP. Bands were visualized on X-ray film using ECL reagents. Arrowheads indicate migration positions of salmon IGFBPs.

et al. (1991). This extraction method has been validated for salmon plasma (Shimizu et al. 2000). IGF-I was measured by RIA as described in Shimizu et al. (2000).

\section{Statistical analysis}

Results of the experiments were analyzed using one-way ANOVA followed by the Fisher protected least-significant difference test (Dowdy \& Weardon 1991) using the Statview 512+ program (Abacus Concepts, Inc., Berkeley, CA, USA). Differences between groups were considered to be significant at $P<0 \cdot 05$.

\section{Results}

Specificity of a polyclonal antiserum against salmon $41 \mathrm{kDa}$ IGFBP was assessed by immunoblotting of purified and semi-purified salmon IGFBPs (Fig. 1). Anti$41 \mathrm{kDa}$ IGFBP immunostained doublet bands at 43 and $41 \mathrm{kDa}$ in the purified $41 \mathrm{kDa}$ IGFBP fraction. Doublet bands at higher molecular mass, presumably aggregation of the 43-41 kDa doublet bands, were also recognized by the antiserum. Anti-41 kDa IGFBP cross-reacted with 


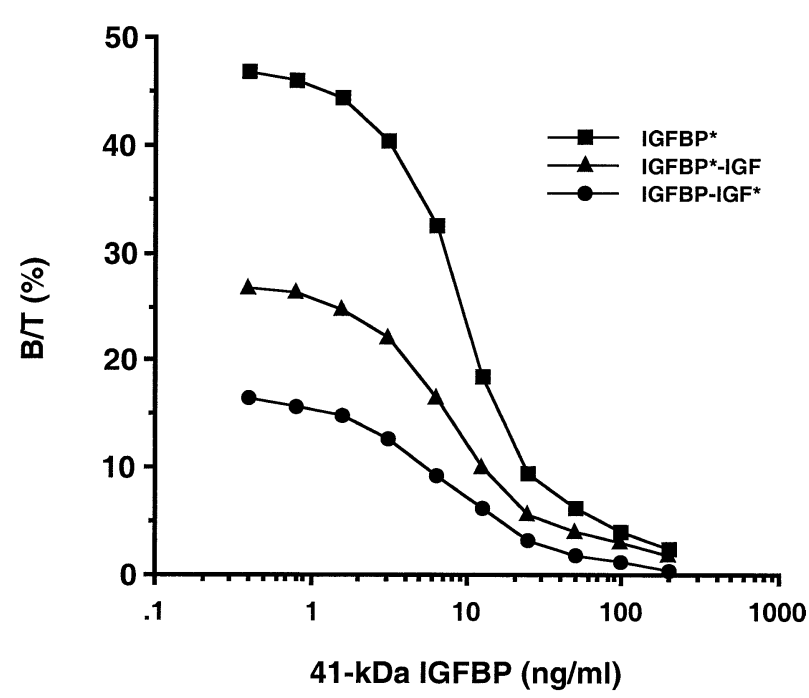

Figure 2 Displacement curves of radiolabeled tracers with unlabeled 41 kDa IGFBP. Approximately 7000 c.p.m. ${ }^{125}$ I-41 kDa IGFBP $\left(\right.$ IGFBP*), ${ }^{125}$ I-41 kDa IGFBP/IGF-I (IGFBP*-IGF-I) and 41 kDa IGFBP $/{ }^{125}$ I-IGF-I (IGFBP-IGF-I*) were incubated with anti-41 kDa IGFBP (1:5000 dilution) and different concentrations of unlabeled $41 \mathrm{kDa}$ IGFBP $(0 \cdot 4-200 \mathrm{ng} / \mathrm{ml})$. Binding $(\mathrm{B} / \mathrm{T})$ is expressed as a percentage of total binding. All values are means of duplicate determinations.

$28 \mathrm{kDa}$ IGFBP weakly but not with $22 \mathrm{kDa}$ IGFBP. This antiserum was used for RIA of salmon $41 \mathrm{kDa}$ IGFBP.

Three differently prepared tracers were examined for development of the RIA; purified $41 \mathrm{kDa}$ IGFBP directly labeled with ${ }^{125} \mathrm{I}$ (IGFBP*), labeled $41 \mathrm{kDa}$ IGFBP crosslinked with unlabeled salmon IGF-I (IGFBP*/IGF-I), and unlabeled $41 \mathrm{kDa}$ IGFBP cross-linked with labeled salmon IGF-I (IGFBP/IGF-I*). All three tracers bound specifically to the antiserum and were displaced with unlabeled $41 \mathrm{kDa}$ IGFBP in a concentration-dependent manner, albeit that total binding differed among tracers (Fig. 2). The tracers were next compared for interaction with added salmon IGF-I with and without the addition of $10 \mathrm{ng} / \mathrm{ml}$ unlabeled $41 \mathrm{kDa}$ IGFBP (Fig. 3). When the combination of unlabeled IGF-I and $41 \mathrm{kDa}$ IGFBP was added to the tracers, the percent of tracer bound increased for IGFBP* and IGFBP*/IGF-I, but remained constant for IGFBP/IGF-I*. Thus, added IGF-I in excess of $2 \mathrm{ng} / \mathrm{ml}$ reduced the displacement of two of the tracers. Total binding of two of the tracers (IGFBP* and IGFBP/ IGF-I*) was not affected by added IGF-I, but the total binding of IGFBP*/IGF-I was increased slightly when IGF-I was added at $10 \mathrm{ng} / \mathrm{ml}$ or greater (Fig. 3). Therefore, IGFBP/IGF-I* was used as the tracer in the RIA.

Using the IGFBP/IGF-I* as tracer, specific and nonspecific binding to the antiserum (1:3000 dilution) under the assay conditions were $20 \cdot 83 \pm 0 \cdot 78 \%$ (mean \pm S.E.M.; $n=8)$ and $0 \cdot 81 \pm 0 \cdot 04 \%(n=8)$ respectively. The half-

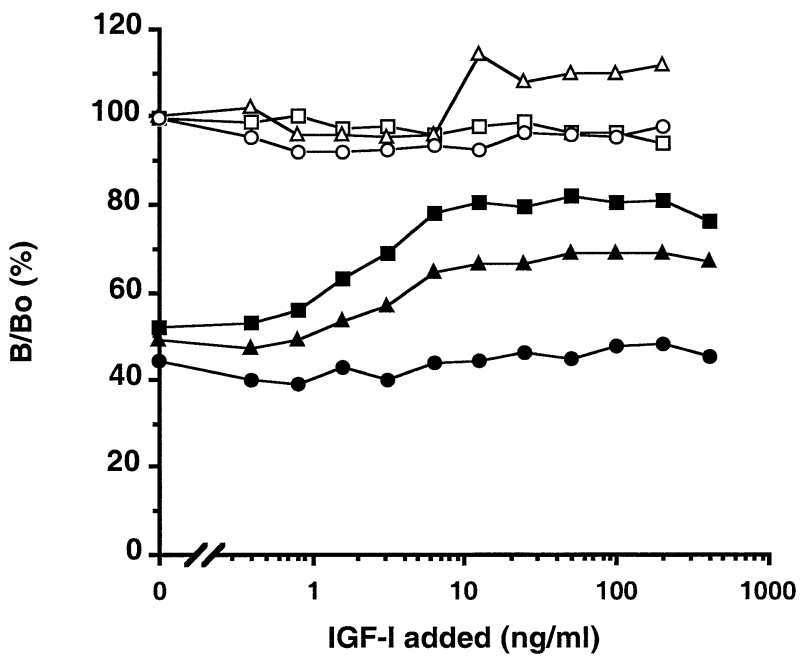

Figure 3 Effect of salmon IGF-I on tracer binding with and without addition of unlabeled 41 kDa IGFBP. Approximately 7000 c.p.m. ${ }^{125}$ I-41 kDa IGFBP (squares), ${ }^{125}$ I-41 kDa IGFBP/IGF-I (triangles) and $41 \mathrm{kDa}$ IGFBP $/{ }^{125} \mathrm{I}$-IGF-I (circles) were incubated with anti-41 kDa IGFBP (1:5000 dilution) and different concentrations of salmon IGF-I $(0 \cdot 4-400 \mathrm{ng} / \mathrm{ml})$ in the presence (closed symbols) or absence (open symbols) of $10 \mathrm{ng} / \mathrm{ml}$ unlabeled $41 \mathrm{kDa}$ IGFBP. Binding $(\mathrm{B} / \mathrm{Bo})$ is expressed as a percentage of specific binding. All values are means of duplicate determinations.

maximal displacement $\left(\mathrm{ED}_{50}\right)$ occurred at $10 \cdot 01 \pm$ $0 \cdot 23 \mathrm{ng} / \mathrm{ml}(n=8)$. The $\mathrm{ED}_{80}$ and $\mathrm{ED}_{20}$ were $3.43 \pm 0 \cdot 13$ and $27 \cdot 13 \pm 0.96 \mathrm{ng} / \mathrm{ml}(n=8)$ respectively. The minimal detection limits of the assay, defined as the mean of the zero standard minus two standard deviations, was $0 \cdot 44 \pm 0 \cdot 07 \mathrm{ng} / \mathrm{ml} \quad(n=8)$. The precision profile (Ekins 1983) of the standard curve indicates that the functional sensitivity, defined as the concentration at which the inter-assay coefficients of variation is $<20 \%$ (Spencer et al. 1995), was $1.56 \mathrm{ng} / \mathrm{ml}(n=10)$. The intra- and inter-assay coefficients of variation estimated at $8.85 \mathrm{ng} / \mathrm{ml}$ using a control serum were $3 \cdot 6 \% \quad(n=10)$ and $11 \cdot 3 \% \quad(n=5)$ respectively. Recovery of purified $41 \mathrm{kDa}$ IGFBP added to chinook salmon serum was $91 \cdot 9 \pm 4 \cdot 5 \%(n=3)$.

In order to further assess possible interference by IGFs in the RIA, the slopes of the IGFBP standards with or without adding IGFs were compared (Fig. 4). Addition of unlabeled salmon IGF-I up to a 1:100 molar ratio did not affect the slope of the standard, and it was parallel to that of salmon serum. Similar results were obtained with human IGF-I and IGF-II (data not shown). Next, the effect of addition of IGFs to plasma on measured $41 \mathrm{kDa}$ IGFBP was examined (Table 1). There was no statistical difference in measured plasma $41 \mathrm{kDa}$ IGFBP with or without IGFs.

Coho salmon plasma from fish in different physiological states showed parallel displacement with the standard (Fig. 5). There was no difference in slope and binding of displacement curve between plasma and serum from coho 


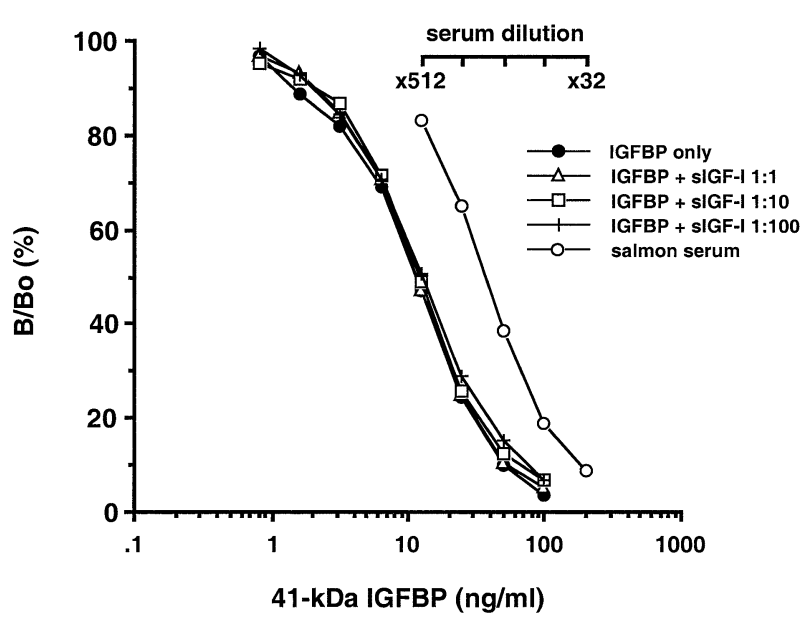

Figure 4 Effect of salmon IGF-I on the standard curve. Approximately 7000 c.p.m. 41 kDa IGFBP $/{ }^{125}$ I-IGF-I were incubated with anti-41 kDa IGFBP (1:3000 dilution) and $41 \mathrm{kDa}$ IGFBP standard (0.8 to $100 \mathrm{ng} / \mathrm{ml})$. Salmon IGF-I (sIGF-I) was added to the standard at a molar ratio of $1: 1,1: 10$ or $1: 100$. Serial dilution (1:32 to 1:512) of serum from spawning chinook salmon is shown for comparison. Binding (B/Bo) is expressed as a percentage of specific binding. All values are means of duplicate determinations.

salmon (data not shown). No displacement was observed with a partially purified salmon $28 \mathrm{kDa}$ IGFBP containing $22 \mathrm{kDa}$ IGFBP as a minor component.

Plasma levels of $41 \mathrm{kDa}$ IGFBP in coho salmon from $\mathrm{GH}$ injection and fasting experiments were measured by RIA. GH treatment caused a significant increase of plasma $41 \mathrm{kDa}$ IGFBP levels, whereas fasting reduced plasma $41 \mathrm{kDa}$ IGFBP levels (Fig. 6). There was a strong positive relationship between total IGF-I and $41 \mathrm{kDa}$ IGFBP levels in individual samples (Fig. 7a). The correlation coefficient was higher with an exponential regression $\left(r^{2}=0.85\right)$ than with a linear regression $\left(r^{2}=0 \cdot 78\right)$. A weaker, but significant, relationship was found between free IGF-I and

Table 1 Effect of addition of IGFs on measured 41 kDa IGFBP in plasma. Data are expressed as means \pm S.E.M., $n=5$

Concentration
$(\mathrm{ng} / \mathrm{ml})$

\section{Added to plasma}

Plasma only

Salmon IGF-I

Human IGF-I 100

Human IGF-II

\section{IGFBP}

$(\mathrm{ng} / \mathrm{ml})$

$107 \cdot 9 \pm 12 \cdot 3$

$109 \cdot 8 \pm 13 \cdot 3$

$106 \cdot 9 \pm 11 \cdot 8$

$108 \cdot 6 \pm 12 \cdot 6$

$103 \cdot 5 \pm 11 \cdot 1$

$102 \cdot 0 \pm 9 \cdot 7$

$108 \cdot 7 \pm 11 \cdot 7$

$110 \cdot 9 \pm 13 \cdot 5$

$107 \cdot 6 \pm 11 \cdot 7$

$104 \cdot 0 \pm 11 \cdot 0$

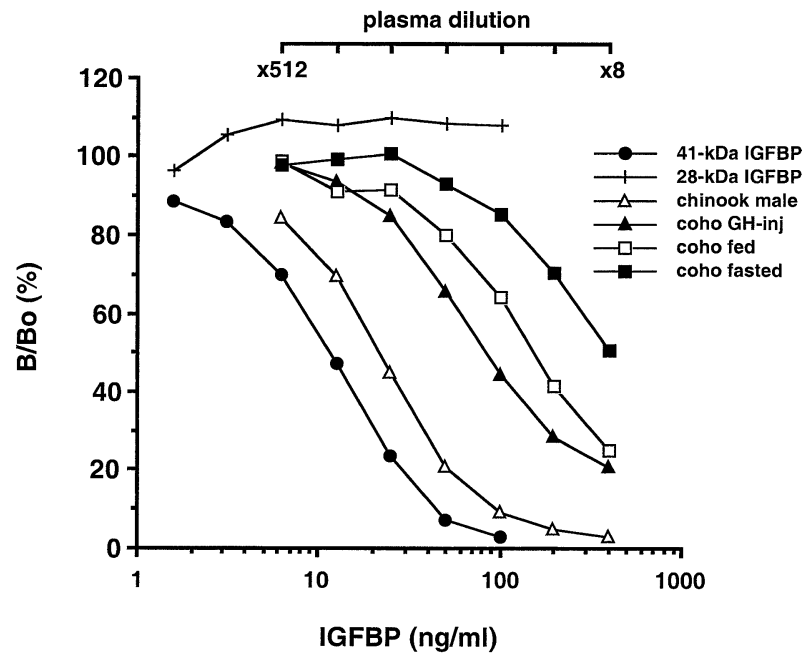

Figure 5 Displacement curves of purified salmon IGFBPs and salmon plasma. Approximately 7000 c.p.m. 41 kDa IGFBP $/{ }^{125}$ I-IGF-I were incubated with anti-41 kDa IGFBP (1:3000 dilution) and serial dilution (1:8 to 1:512) of plasma from coho salmon under different physiological states. Displacement curves of plasma are compared with that of the standard. Binding $(\mathrm{B} / \mathrm{Bo})$ is expressed as a percentage of specific binding. All values are means of duplicate determinations.

$41 \mathrm{kDa}$ IGFBP (Fig. 7b). The relationship was best represented by a polynomial regression $\left(r^{2}=0 \cdot 61\right)$.

Changes in plasma IGF-I and $41 \mathrm{kDa}$ IGFBP levels during smoltification of coho salmon were measured by RIAs (Fig. 8). The condition factor, a morphological index of smoltification, declined from mid March to its lowest point in early May indicating the completion of smoltification (data not shown). Plasma IGF-I exhibited peaks in mid March and late April (Fig. 8). Plasma $41 \mathrm{kDa}$ IGFBP, on the other hand, showed a transient peak in late March, corresponding to the first peak of IGF-I, and stayed relatively constant thereafter (Fig. 8).

\section{Discussion}

In this study, an RIA for salmon $41 \mathrm{kDa}$ IGFBP, a candidate for fish IGFBP-3, has been established and validated for the first time. In RIAs for mammalian IGFBP-3, the preparation of radiotracer is one of the more critical aspects. Baxter \& Martin (1986) reported that when purified human IGFBP-3 was labeled directly with iodine, an unacceptably high non-specific binding $(>15 \%$ of total radioactivity) was observed. In order to overcome this problem, IGFBP-3 is indirectly labeled by crosslinking with ${ }^{125}$ I-IGF-I (Baxter \& Martin 1986), or labeled IGFBP-3 is purified by gel filtration (Blum et al. 1990). In the present study, three different tracers were prepared: ${ }^{125} \mathrm{I}-41 \mathrm{kDa}$ IGFBP (IGFBP*), IGFBP* crosslinked with unlabeled salmon IGF-I (IGFBP*/IGF-I) and 


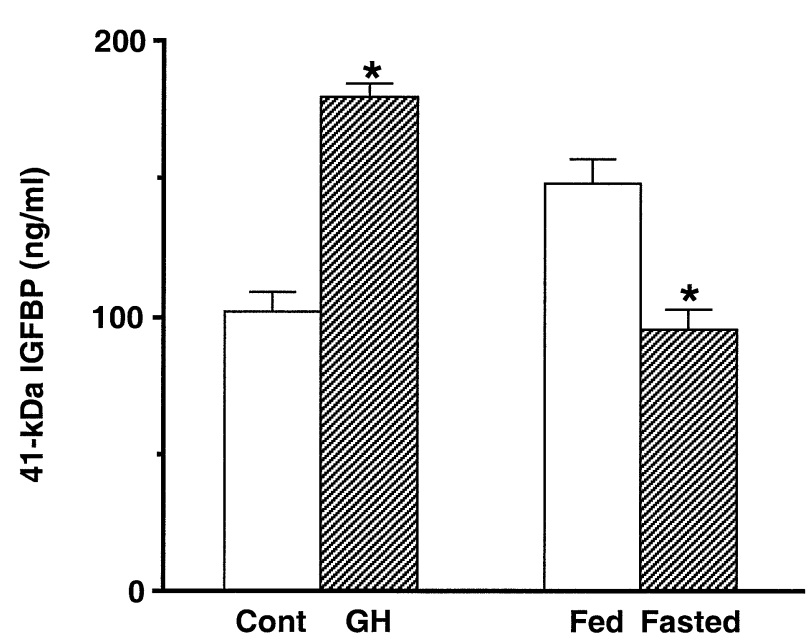

Figure 6 Plasma 41 kDa IGFBP levels measured by RIA. Plasma from coho salmon injected twice with saline (Cont; $n=10$ ) or $0 \cdot 1 \mu \mathrm{g} / \mathrm{g} \mathrm{GH}(n=9)$, and coho salmon fed $(n=10)$ or fasted $(n=10)$ for 1 month were measured for $41 \mathrm{kDa}$ IGFBP by RIA. Vertical bars represent S.E.M. Asterisks indicate significant difference between treatments for each experiment $(P<0 \cdot 05)$.

IGFBP/IGF-I*. Unlike mammalian IGFBP-3, none of the tracers showed high non-specific binding in the RIA. There were, however, differences in the total binding among tracers. This may be partly because of the different specific activities of the tracers. It is also possible that unlabeled IGFBP in IGFBP/IGF-I*, which was not cross-linked with IGF-I*, influenced the total binding of the tracer. Despite the difference in the total binding, all three tracers were specifically displaced by adding unlabeled IGFBPs. In most RIAs for IGFs, IGFBPs interfere with the accurate measurement of IGFs and therefore IGF must be separated from IGFBPs prior to RIA (Bang et al. 1994). On the other hand, IGFs generally do not affect the RIAs for IGFBPs, with one exception: the RIA for IGFBP-6 (Baxter \& Saunders 1992). We thus examined the effect of IGF on the standard curve in our salmon RIA. Total binding was not influenced by addition of salmon IGF-I except for IGFBP*/IGF-I. However, when the tracers were competed with unlabeled $41 \mathrm{kDa}$ IGFBP in the presence or absence of exogenous IGF-I, displacement of IGFBP* and IGFBP*/IGF-I with unlabeled IGFBP was diminished by the presence of IGF-I. An explanation for the interference by IGF-I may be that immunoreactivity of IGF-bound $41 \mathrm{kDa}$ IGFBP is lower than that of unoccupied $41 \mathrm{kDa}$ IGFBP. Although the exact mechanism of the interference by IGF is not clear, IGFBP/IGF-I* is practically the only tracer which is not affected by IGF-I under the assay conditions, and was therefore chosen for the tracer.

In order to further assess the influence of IGF in the RIA using IGFBP/IGF-I*, various amounts of IGFs (salmon IGF-I, and human IGF-I and IGF-II) were added to the standard and plasma. Neither the slope of the
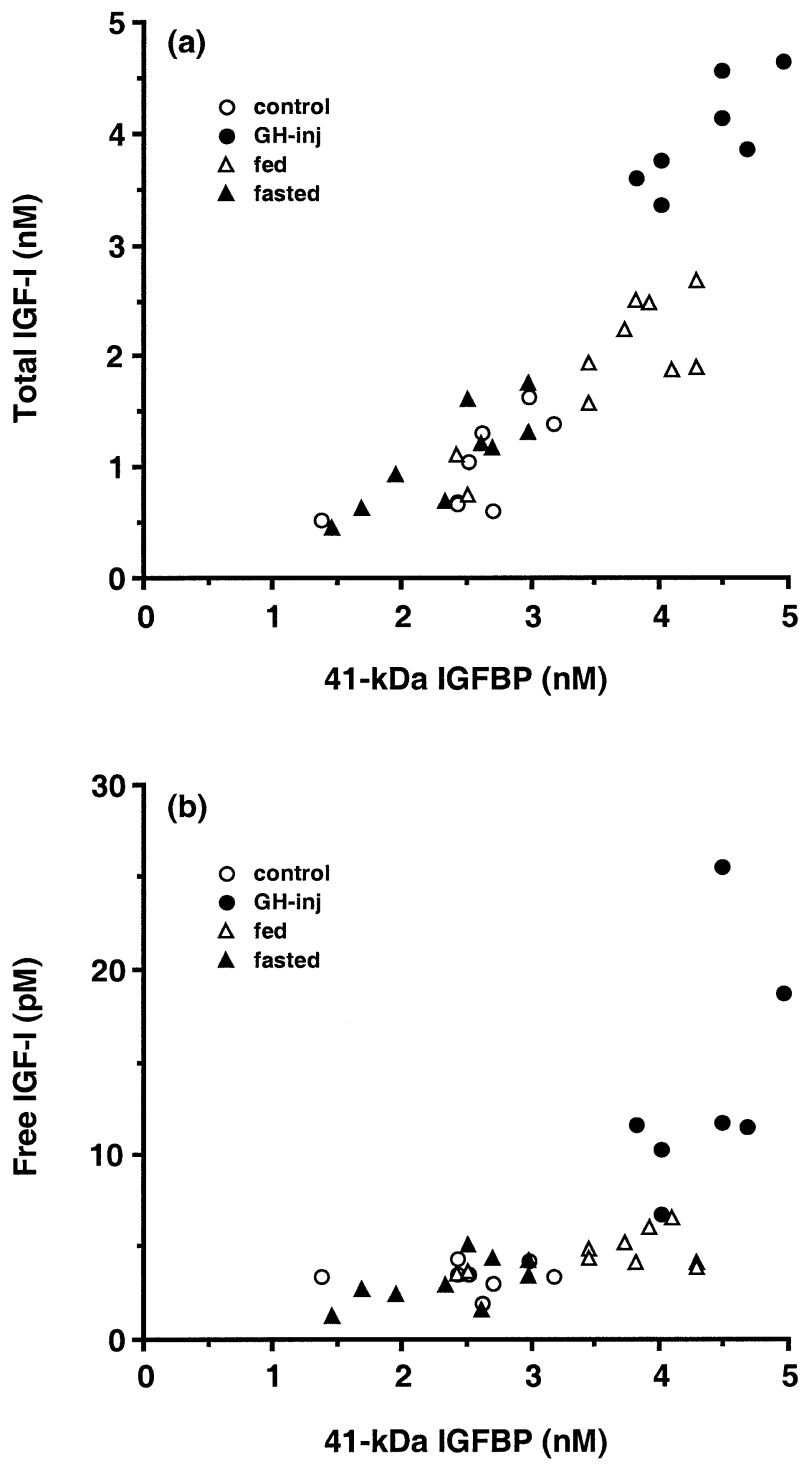

Figure 7 Relationship between plasma 41 kDa IGFBP and total IGF-I levels (a), and plasma 41 kDa IGFBP and free IGF-I levels (b). Data on plasma total and free IGF-I levels are from Shimizu et al. (1999).

standard curve nor measured plasma IGFBP levels were affected by addition of IGFs. These results confirm that RIA using IGFBP/IGF-I* is not influenced by varying levels of IGF. This implies that plasma can be directly assayed by the RIA without extraction to separate IGF and its binding proteins. No cross-reactivity was detected with other salmon IGFBPs (i.e. 28 and $22 \mathrm{kDa}$ IGFBPs) in the RIA for $41 \mathrm{kDa}$ IGFBP, despite the fact that anti-41 kDa IGFBP weakly recognized the $28 \mathrm{kDa}$ IGFBP in Western blotting. These data demonstrate validity of the RIA for measuring $41 \mathrm{kDa}$ IGFBP. Parallel displacement of coho 


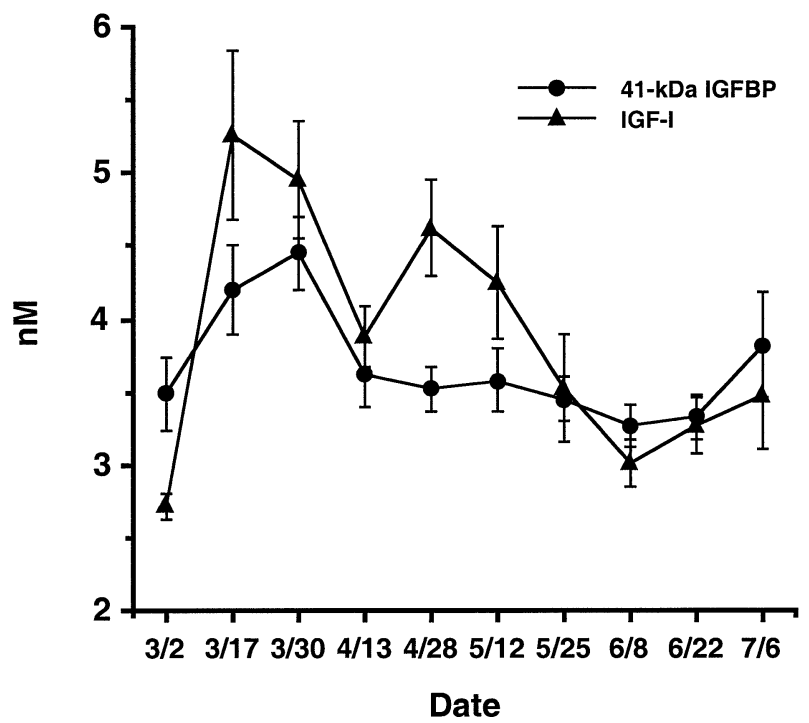

Figure 8 Changes in plasma 41 kDa IGFBP and IGF-I levels during smoltification of coho salmon. $n=12$ per each point. Vertical bars represent S.E.M.

salmon plasma with standard suggests that this RIA is applicable to other salmonid species.

Plasma IGFBP-3 levels are primarily influenced by GH and nutritional status: GH stimulates hepatic synthesis of IGFBP-3, probably indirectly through IGF-I (Villafuerte et al. 1994), and fasting or malnutrition causes a decrease in circulating IGFBP-3 (Clemmons \& Underwood 1991). In fish, candidates for IGFBP-3 have been detected based on molecular size and responses to $\mathrm{GH}$ injection and fasting on Western ligand blotting (Kelley et al. 1992, Siharath et al. 1995, Shimizu et al. 1999, Park et al. 2000). Recently, the cDNA sequence of most of a tilapia IGFBP-3 has been determined (Cheng et al. 2002). As determined by RNAse protection assay, the tilapia IGFBP-3 mRNA increased in response to GH treatment. Consistent with the observation by Western ligand blotting and RNAse protection assay, GH treatment increased measured $41 \mathrm{kDa}$ IGFBP levels about 1.8-fold, and fasting decreased its levels by one-third compared with the fed control. These findings suggest that the $41 \mathrm{kDa}$ IGFBP is functionally IGFBP-3.

Mammalian IGFBP-3 carries most of the circulating IGF-I. In general, there is a positive relationship between IGFBP-3 and IGF-I levels (Baxter \& Martin 1986, Frystyk et al. 1998). In the present study, plasma $41 \mathrm{kDa}$ IGFBP levels correlated positively with total IGF-I levels and molarity of the $41 \mathrm{kDa}$ IGFBP was comparable with that of total IGF-I. These comparisons indicate that the $41 \mathrm{kDa}$ IGFBP is a main carrier of circulating IGF-I, as is IGFBP-3 in mammals. Free IGF-I levels also correlated positively with $41 \mathrm{kDa}$ IGFBP levels, but the regression coefficient was not as high as for total IGF-I. This might be due to other IGFBP regulation of free IGF-I levels (Frystyk et al. 1997).

In spring, juvenile salmon migrate to the ocean to grow. Prior to down-stream migration, juvenile salmon undergo the parr-smolt transformation (smoltification), which is a pre-adaptation to ocean life involving behavioral, morphological and physiological changes (for review see Hoar 1988). The GH-IGF-I endocrine axis plays a central role in regulation of smoltification since this axis promotes growth and seawater adaptability of juveniles, both of which are important for successful smoltification (Dickhoff et al. 1997). In the present study, plasma IGF-I showed peaks in March and April. Discrete peaks of IGF-I in plasma during smoltification have been reported in chinook salmon (Beckman et al. 1998), coho salmon (Larsen et al. 2001) and Atlantic salmon (Salmo salar; Ágústsson et al. 2001). Those IGF-I profiles seem to be influenced by environmental factors such as photoperiod, water temperature and feeding ration (Beckman et al. 1998, McCormick et al. 2000, Larsen et al. 2001). Plasma $41 \mathrm{kDa}$ IGFBP, on the other hand, showed a single peak in March and stayed relatively constant thereafter, whereas IGF-I showed a second peak in April. This suggests that the molar ratio of IGF-I to $41 \mathrm{kDa}$ IGFBP fluctuated during smoltification. The difference in the molar ratio could influence availability of IGF-I to target tissues. In this regard, the $41 \mathrm{kDa}$ IGFBP may regulate salmon smoltification via controlling IGF-I availability. However, we did not measure levels of free IGF-I, which is believed to be a biologically active form available to the receptor, nor of other IGFBP levels in those fish. In order to fully understand regulation of salmon smoltification by the GH-IGF-I axis including IGFBPs, more detailed studies are needed.

In conclusion, we have established an RIA for salmon $41 \mathrm{kDa}$ IGFBP. Quantification of $41 \mathrm{kDa}$ IGFBP in plasma from fish in different physiological states suggests that the $41 \mathrm{kDa}$ IGFBP is salmon IGFBP-3 and it acts as a main carrier of circulating IGF-I. Differences in the molar ratio between IGF-I and $41 \mathrm{kDa}$ IGFBP possibly influence availability of IGF-I from the circulation to the target tissues during smoltification.

\section{Acknowledgements}

We thank Brad Gadberry and Paul Parkins, Northwest Fisheries Science Center, National Marine Fisheries Service, Seattle, WA, USA, for maintenance of the experimental fish and their help in blood collection. This work was supported by grants from the US Department of Agriculture, NRICGP, Animal Growth and Nutrient Utilization Program (Project 2001-03320) and Bonneville Power Administration (Projects 92-022-00 and 93056-00). This publication is also funded by the Joint Institute for the Study of the Atmosphere and Ocean 
(JISAO) under NOAA Cooperative Agreement No. NA17RJ11232, Contribution \#971.

\section{References}

Ágústsson T, Sundell K, Sakamoto T, Johansson V, Ando M \& Bjšrnsson BTh 2001 Growth hormone endocrinology of Atlantic salmon (Salmo salar): pituitary gene expression, hormone storage, secretion and plasma levels during parr-smolt transformation. Journal of Endocrinology 170 227-234.

Bang P, Baxter RC, Blum WF, Breier BH, Clemmons DR, Hall K, Hintz RL, Holly JM, Rosenfeld RG \& Zapf J 1994 Valid measurements of total IGF concentrations in biological fluids. Recommendations from the 3rd International Symposium on Insulin-like Growth Factors. Journal of Endocrinology 143 C1-C2.

Bauchat JR, Busby WH Jr, Garmong A, Swanson P, Moore J, Lin M \& Duan C 2001 Biochemical and functional analysis of a conserved IGF-binding protein isolated from rainbow trout (Oncorhynchus mykiss) hepatoma cells. Journal of Endocrinology 170 619-628.

Baxter RC \& Martin JL 1986 Radioimmunoassay of growth hormone-dependent insulin-like growth factor binding protein in human plasma. Journal of Clinical Investigation 78 1504-1512.

Baxter RC \& Saunders H 1992 Radioimmunoassay of insulin-like growth factor-binding protein-6 in human serum and other body fluids. Journal of Endocrinology 134 133-139.

Beckman BR, Larsen DA, Moriyama S, Lee-Pawlak B \& Dickhoff WW 1998 Insulin-like growth factor-I and environmental modulation of growth during smoltification of spring chinook salmon (Oncorhynchus tshawystscha). General and Comparative Endocrinology 109 325-335.

Blum WF, Ranke MB, Kietzmann K, Gauggel E, Zeisel HJ \& Bierich JR 1990 A specific radioimmunoassay for the growth hormone (GH)-dependent somatomedin-binding protein: its use for diagnosis of GH deficiency. Journal of Clinical Endocrinology and Metabolism 70 1292-1298.

Breier BH, Gallaher BW \& Gluckman PD 1991 Radioimmunoassay for insulin-like growth factor-I: solutions to some potential problems and pitfalls. Journal of Endocrinology 128 347-357.

Catt KJ 1976 Receptors for gonadotropic hormones. In Methods in Receptor Research, vol 1, pp 175-250. Ed M Blecher. New York, NY: Marcel Dekker.

Cheng R, Chang K-M \& Wu J-L 2002 Different temporal expressions of tilapia (Oreochromis mossambicus) insulin-like growth factor-I and IGF binding protein-3 after growth hormone induction. Marine Biotechnology 4 218-225.

Clemmons DR \& Underwood LE 1991 Nutritional regulation of IGF-I and IGF binding proteins. Annual Review of Nutrition 11 393-412.

Dickhoff WW, Beckman BR, Larsen DA, Duan C \& Moriyama S 1997 The role of growth in endocrine regulation of salmon smoltification. Fish Physiology and Biochemistry 17 231-236.

Dowdy S \& Weardon S 1991 Statistics for Research, pp 303-305. New York, NY: Wiley.

Duan C, Ding J, Li Q, Tsai W \& Pozios K 1999 Insulin-like growth factor binding protein 2 is a growth inhibitory protein conserved in zebrafish. PNAS 96 15274-15279.

Ekins RP 1983 The precision profile: its use in assay design, assessment and quality control. In Immunoassays for Clinical Chemistry, pp 76-105. Eds WM Hunter \& JET Corrie. Edinburgh: Churchill Livingstone.

Frystyk J, Grofte T, Skjaerbaek C \& Orskov H 1997 The effect of oral glucose on serum free insulin-like growth factor-I and -II in health adults. Journal of Clinical Endocrinology and Metabolism 82 3124-3127.

Frystyk J, Gronbaek H, Skjaerbaek C, Flyvbjerg A, Orskov H \& Baxter RC 1998 Developmental changes in serum levels of free and total insulin-like growth factor I (IGF-I), IGF-binding protein-1 and -3 , and the acid-labile subunit in rats. Endocrinology $1394286-4292$.

Funkenstein B, Tsai W, Maures T \& Duan C 2002 Ontogeny, tissue distribution, and hormonal regulation of insulin-like growth factor binding protein-2 (IGFBP-2) in a marine fish, Sparus aurata. General and Comparative Endocrinology 128 112-122.

Hoar WS 1988 The physiology of smolting salmonids. In Fish Physiology, vol 11B, pp 275-343. Eds WS Hoar \& D Randall. Orlando, FL: Academic Press.

Jones JI \& Clemmons DR 1995 Insulin-like growth factors and their binding proteins: biological actions. Endocrine Reviews 16 3-34.

Kelley KM, Siharath K \& Bern HA 1992 Identification of insulin-like growth factor-binding proteins in the circulation of four teleost fish species. Journal of Experimental Zoology 263 220-224.

Kelley KM, Haigwood JT, Perez M \& Galima MM 2001 Serum insulin-like growth factor binding proteins (IGFBPs) as markers for anabolic/catabolic condition in fishes. Comparative Biochemistry and Physiology 129B 229-236.

Laemmli UK 1970 Cleavage of structural proteins during the assembly of the head of bacteriophage T4. Nature 227 680-685.

Larsen DA, Beckman BR \& Dickhoff WW 2001 The effect of low temperature and fasting during the winter on metabolic stores and endocrine physiology (insulin, insulin-like growth factor-I, and thyroxine) of coho salmon, Oncorhynchus kisutch. General and Comparative Endocrinology 123 308-323.

Maures TJ \& Duan C 2002 Structure, developmental expression, and physiological regulation of zebrafish IGF binding protein-1. Endocrinology 143 2722-2731.

McCormick SD, Moriyama S \& Bjšrnsson BTh 2000 Low temperature limits photoperiod control of smolting in Atlantic salmon through endocrine mechanisms. American Journal of Physiology 278 R1352-R1361.

Mohan S \& Baylink DJ 2002 IGF-binding proteins are multifunctional and act via IGF-dependent and -independent mechanisms. Journal of Endocrinology 175 19-31.

Moriyama S, Swanson P, Nishii M, Takahashi A, Kawauchi H, Dickhoff WW \& Plisetskaya EM 1994 Development of a homologous radioimmunoassay for coho salmon insulin-like growth factor-I. General and Comparative Endocrinology 96 149-161.

Niu P-D \& Le Bail P-Y 1993 Presence of insulin-like growth factor binding protein (IGF-BP) in rainbow trout (Oncorhynchus mykiss) serum. Journal of Experimental Zoology 265 627-636.

Park R Shepherd BS, Nishioka RS, Grau EG \& Bern HA 2000 Effects of homologous pituitary hormone treatment on serum insulin-like growth-factor-binding proteins (IGFBPs) in hypophysectomized tilapia, Oreochromis mossambicus, with special reference to a novel 20-kDa IGFBP. General and Comparative Endocrinology 117 404-412.

Rajaram S, Baylink DJ \& Mohan S 1997 Insulin-like growth factorbinding proteins in serum and other biological fluids: regulation and functions. Endocrine Reviews 18 801-831.

Rechler MM 1993 Insulin-like growth factor binding proteins. Vitamins and Hormones 47 1-114.

Shimasaki S \& Ling N 1991 Identification and molecular characterization of insulin-like growth factor binding proteins (IGFBP-1, -2, -3, -4, -5 and -6). Progress in Growth Factor Research $3243-266$.

Shimizu M, Swanson P \& Dickhoff WW 1999 Free and proteinbound insulin-like growth factor-I (IGF-I) and IGF-binding proteins in plasma of coho salmon, Oncorhynchus kisutch. General and Comparative Endocrinology 115 398-405.

Shimizu M, Swanson P, Fukada H, Hara A \& Dickhoff WW 2000 Comparison of extraction methods and assay validation for salmon insulin-like growth factor-I using commercially available components. General and Comparative Endocrinology 119 26-36. 
Shimizu M, Swanson P, Hara A \& Dickhoff WW 2003 Purification of a $41-\mathrm{kDa}$ insulin-like growth factor binding protein from serum of chinook salmon, Oncorhynchus tshawytscha. General and Comparative Endocrinology 132 103-111.

Siharath K, Nishioka RS, Madsen SS \& Bern HA 1995 Regulation of IGF-binding proteins by growth hormone in the striped bass, Morone saxatilis. Molecular Marine Biology and Biotechnology 4 171-178.

Siharath K, Kelley KM \& Bern HA 1996 A low-molecular-weight (25-kDa) IGF-binding protein is increased with growth inhibition in the fasting striped bass, Morone saxatilis. General and Comparative Endocrinology 102 307-316.

Spencer CA, Takeuchi M, Kazarosyan M, MacKenzie F, Beckett GJ \& Wilkinson E 1995 Interlaboratory/intermethod differences in functional sensitivity of immunometric assays of thyrotropin
(TSH) and impact on reliability of measurement of subnormal concentrations of TSH. Clinical Chemistry 41 367-374.

Upton Z, Chan SJ, Steiner DF, Wallace JC \& Ballard FJ 1993 Evolution of insulin-like growth factor binding proteins. Growth Regulation 3 29-32.

Villafuerte BC, Koop BL, Pao CI, Gu L, Birdsong GG \& Phillips LS 1994 Coculture of primary rat hepatocytes and nonparenchymal cells permits expression of insulin-like growth factor binding protein-3 in vitro. Endocrinology 134 2044-2050.

Received 16 April 2003

Accepted 13 May 2003

Made available online as an Accepted Preprint 21 May 2003 